\title{
Inhibition of struvite crystallization by tetrasodium pyrophosphate in artificial urine - chemical and physical aspects of nucleation and growth
}

\section{Supporting information}

\author{
Marcin Olszynski ${ }^{\text {a }}$, Jolanta Prywer ${ }^{\text {a }}$, Ewa Mielniczek- Brzóska ${ }^{b}$ \\ ${ }^{a}$ Institute of Physics, Lodz University of Technology, ul. Wólczańska 219, 93-005 Łódź, Poland \\ ${ }^{\mathrm{b}}$ Institute of Chemistry, Environment Protection and Biotechnology, Jan Długosz University of \\ Częstochowa, ul. Armii Krajowej 13/15, 42-200 Częstochowa, Poland
}

The addition of tetrasodium pyrophosphate causes an increase in the initial value of $\mathrm{pH}$ of artificial urine. During our crystallization experiments the initial values of $\mathrm{pH}$ were equal to 6.12, $6.16,6.22,6.32$ and 6.66 for concentrations of tetrasodium pyrophosphate equal to $0,0.25,0.5$, 1.0 and $2.5 \mathrm{mg} / \mathrm{ml}$, respectively. The changes in initial value of $\mathrm{pH}$ can be explained on the basis of theoretical chemical analysis. Presence of tetrasodium pyrophosphate $\left(\mathrm{Na}_{4} \mathrm{P}_{2} \mathrm{O}_{7}\right)$ in the solution of artificial urine causes the splitting of $\mathrm{Na}_{4} \mathrm{P}_{2} \mathrm{O}_{7}$ into the $\mathrm{Na}^{+}$and $\mathrm{P}_{2} \mathrm{O}_{7}{ }^{4-}$ ions. This process takes place according to the following reaction:

$$
\mathrm{Na}_{4} \mathrm{P}_{2} \mathrm{O}_{7} \rightarrow 4 \mathrm{Na}^{+}+\mathrm{P}_{2} \mathrm{O}_{7}^{4-} \text {. }
$$

As a result of reaction $\mathrm{S} 1$ in the solution of artificial urine, the $\mathrm{P}_{2} \mathrm{O}_{7}{ }^{4-}$ ion appears. Then the multistage hydrolysis processes take place. These processes occur according to the following reactions:

$$
\begin{aligned}
& \mathrm{P}_{2} \mathrm{O}_{7}^{4-}+\mathrm{H}_{2} \mathrm{O} \leftrightarrow \mathrm{HP}_{2} \mathrm{O}_{7}^{3-}+\mathrm{OH}^{-} \\
& \mathrm{HP}_{2} \mathrm{O}_{7}^{3-}+\mathrm{H}_{2} \mathrm{O} \leftrightarrow \mathrm{H}_{2} \mathrm{P}_{2} \mathrm{O}_{7}^{2-}+\mathrm{OH}^{-} \\
& \mathrm{H}_{2} \mathrm{P}_{2} \mathrm{O}_{7}^{2-}+\mathrm{H}_{2} \mathrm{O} \leftrightarrow \mathrm{H}_{3} \mathrm{P}_{2} \mathrm{O}_{7}^{-}+\mathrm{OH}^{-} \\
& \mathrm{H}_{2} \mathrm{P}_{2} \mathrm{O}_{7}^{2-}+\mathrm{H}_{2} \mathrm{O} \leftrightarrow \mathrm{H}_{4} \mathrm{P}_{2} \mathrm{O}_{7}+\mathrm{OH}^{-}
\end{aligned}
$$

It is seen that all these reactions may lead to the increase in $\mathrm{pH}$ value. The changes in concentrations of the $\mathrm{HP}_{2} \mathrm{O}_{7}{ }^{3-}, \mathrm{H}_{2} \mathrm{P}_{2} \mathrm{O}_{7}{ }^{2-}, \mathrm{H}_{3} \mathrm{P}_{2} \mathrm{O}_{7}{ }^{-}$ions and the $\mathrm{H}_{4} \mathrm{P}_{2} \mathrm{O}_{7}$ molecule taking part in the reactions S2-S5 are presented in Fig. S1. Typical initial value of $\mathrm{pH}$ of artificial urine equals about 6.0. From Fig. S1, it follows that for $\mathrm{pH}$ about 6.0 the $\mathrm{HP}_{2} \mathrm{O}_{7}{ }^{3-}$ ion reaches the highest 
concentration. This means that the increase in initial value of $\mathrm{pH}$ observed during our experiments is caused by the hydrolysis of the $\mathrm{P}_{2} \mathrm{O}_{7}{ }^{4-}$ ion and the formation of the $\mathrm{HP}_{2} \mathrm{O}_{7}{ }^{3-}$ ion (reactions S2). This process leads to the increase in concentration of the $\mathrm{OH}^{-}$ions in the solution of artificial urine and in this way the initial $\mathrm{pH}$ is increased. Additionally, increasing concentration of tetrasodium pyrophosphate causes the increase in concentration of the $\mathrm{P}_{2} \mathrm{O}_{7}{ }^{4-}$ ion (Fig. S2). In this way the initial value of $\mathrm{pH}$ increases with increasing amount of tetrasodium pyrophosphate present in artificial urine.

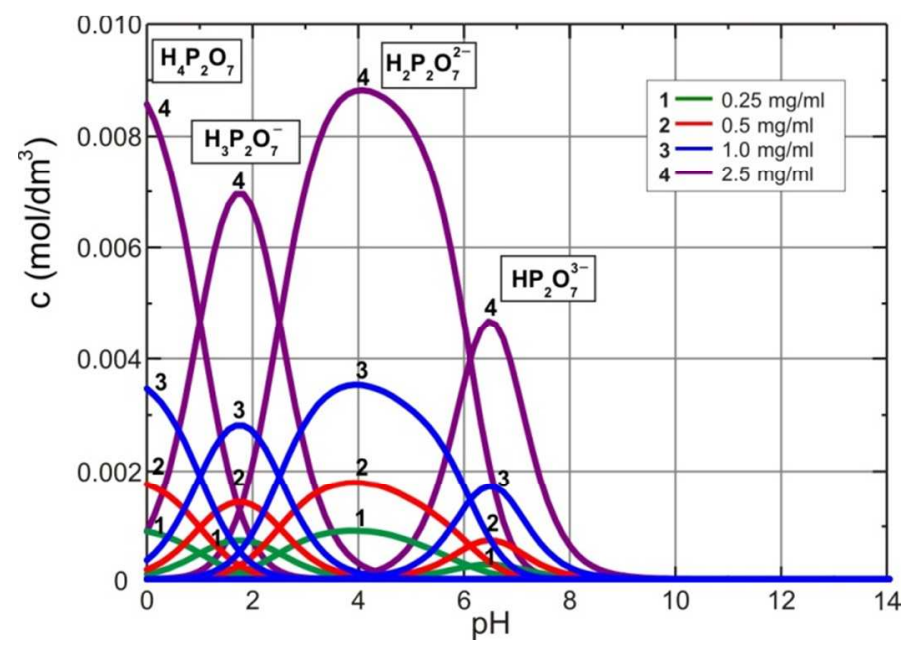

Fig. S1. Dependence of the concentration of different complexes formed at the participation of the $\mathrm{P}_{2} \mathrm{O}_{7}^{4-}$ ion for different concentrations of tetrasodium pyrophosphate given in the inset.

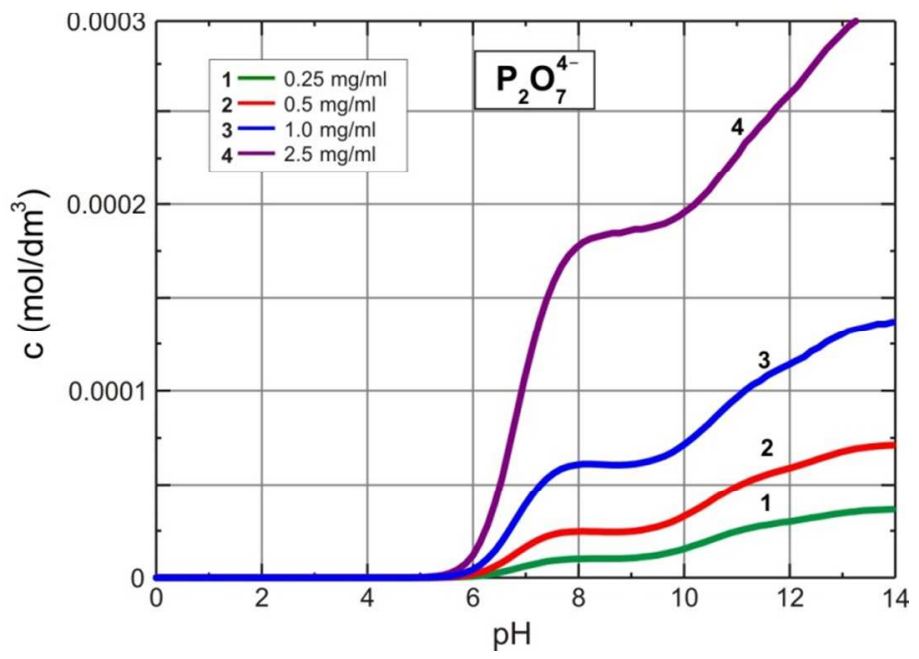

Fig. S2. Dependence of the concentration of the $\mathrm{P}_{2} \mathrm{O}_{7}{ }^{4-}$ ion on $\mathrm{pH}$ of artificial urine for different concentrations of tetrasodium pyrophosphate given in the inset. 